\title{
ERRATUM
}

\section{Erratum to: The Cultural Value of Invasive Species: A Case Study from Semi-Arid Northeastern Brazil}

Lucilene Lima dos Santos ${ }^{*}, 1$, André Luiz Borba do Nascimento ${ }^{2}$, Fábio José Vieira ${ }^{3}$, Valdeline Atanázio da Silva ${ }^{4}$, Robert Voeks ${ }^{5}$, and Ulysses Paulino Albuquerque ${ }^{*, 2}$

${ }^{1}$ Instituto Federal de Educação, Ciência e Tecnologia de Pernambuco, Bairro São Pedro-Belo Jardim, Pernambuco, Brazil

${ }^{2}$ Universidade Federal Rural de Pernambuco, Departamento de Biologia, Laboratório de Etnobiologia Aplicada e Teórica, Recife, Pernambuco, Brazil

${ }^{3}$ Universidade Estadual do Piauí, Departamento de Biologia, Picos, Piauí, Brazil

${ }^{4}$ Universidade Federal Rural de Pernambuco, Departamento de Biologia, Serra Talhada, Pernambuco, Brazil

${ }^{5}$ Department of Geography, California State University, Fullerton, California, United States

*Corresponding author; e-mail: upa@db.ufrpe.br

\section{Erratum to: Economic Botany}

DOI 10.1007/s12231-014-9281-8

The wrong versions of Figs. 4 and 5 were inadvertently published. The correct figures are reproduced here. 
Habit of the species (\%)

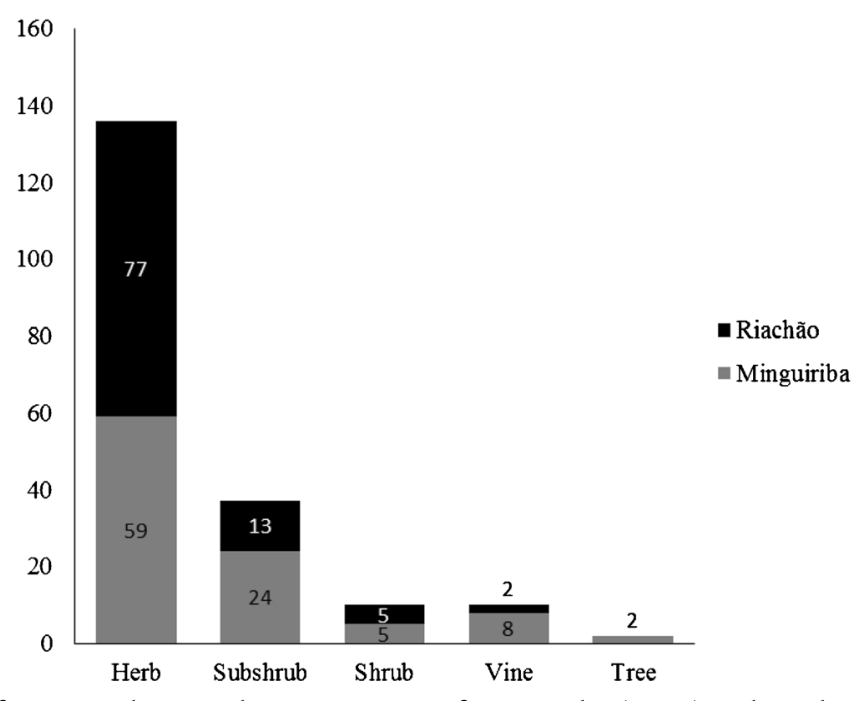

Fig. 4. Habits of invasive plants in the communities of Minguiriba (Ceará) and Riachão de Malhada de Pedra (Pernambuco), northeastern Brazil. The values in this figure represent the total number of species represented in each habit.

Uses (\%)

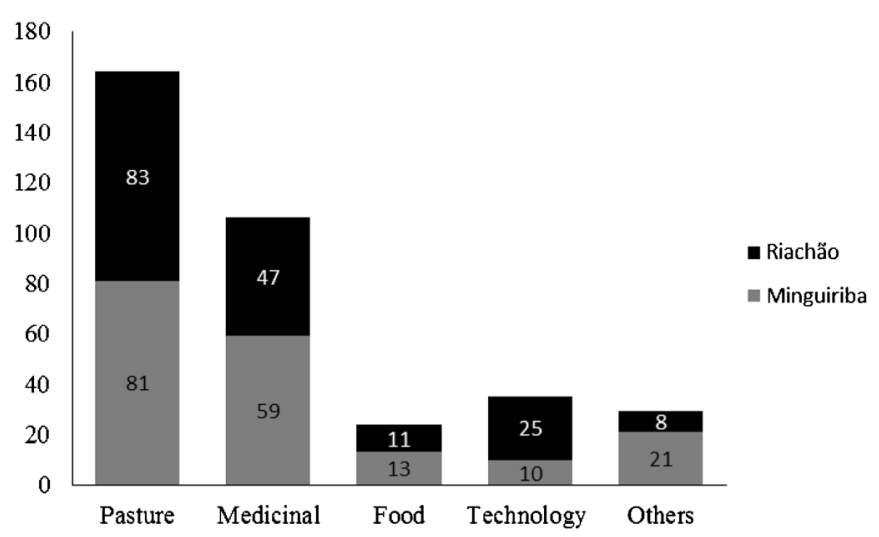

Fig. 5. Reported uses for invasive plants in the communities of Minguiriba (CE) and Riachão de Malhada de Pedra (PE), northeastern Brazil. 